\title{
Triple oral combination therapy in patients with idiopathic pulmonary arterial hypertension and recurrent vessel dissection of inoperable pulmonary artery aneurysm
}

\section{Marco Vatrano , Luana Orlandob, Francesco Cassadontea, Pierpaolo Di Miccoc, Vincenzo Antonio Ciconte ${ }^{a}$, Vincenzo Russo ${ }^{d}$, Egidio Imbalzano ${ }^{b}$}

a UTIC and Cardiology, Hospital "Pugliese-Ciaccio" of Catanzaro, Italy

${ }^{b}$ Department of Clinical and Experimental Medicine, University of Messina, Italy

' Buonconsiglio Fatebenefratelli Hospital, Department of Medicine, Naples, Italy

a Department of Medical Translational Sciences, Division of Cardiology, Monaldi Hospital, University of Campania

"Luigi Vanvitelli", Naples, Italy

\section{ARTICLE INFO}

Article history:

Submitted: 15. 4. 2021

Revised: 21. 6. 2021

Accepted: 24. 7. 2021

Available online: 30.11 .2021

\section{Klíčová slova:}

Aneurysma na plicnici

Disekce plicnice

Plicní hypertenze

\section{SOUHRN}

Kontext: Aneurysma na plicnici je vzácné postižení v důsledku zátěže cévní stěny při postupné dilataci. Jednoznačná definice a údaje o prevalenci tohoto postižení nejsou k dispozici. Plicní hypertenze je navíc život ohrožující a progredující postižení vyžadující specifickou léčbu.

Kazuistika: Popisujeme prípad 62leté bělošky s idiopatickou plicní hypertenzí a inoperabilním obrovským aneurysmatem na opakovaně disekované plicnici. Diagnóza byla stanovena snadno echokardiograficky a výpočetní tomografií. Obtížné bylo naopak rozhodování o léčbě, protože operatéři odmítli provést chirurgické odstranění aneurysmatu. Pacientku jsme léčili farmakologicky medikací specificky určenou pro plicní hypertenzi s cílem snízit tlak na plicnici.

Diskuse: Popisujeme velmi vzácné a nesmírně závažné postižení charakterizované prítomností plicní hypertenze účinně léčené vhodnou perorální trojkombinací spolu s inoperabilním aneurysmatem na opakovaně disekované plicnici.

(c) 2021, ČKS.

\section{ABSTRACT}

Background: Pulmonary artery aneurysm is a rare condition related to the stress that the vascular wall undergoes with progressive dilation. A clear definition and its prevalence are not available. Pulmonary arterial hypertension is also a life-threatening and progressive condition which requires specific therapies.

Case report: We describe the case of a 62-year-old Caucasian woman with idiopathic pulmonary arterial hypertension and inoperable giant pulmonary artery aneurysm associated with recurrent vessel dissection. Diagnosis was simple with the use of echocardiography and computed tomography. Conversely, deciding on the treatment was difficult, because surgeons declined to perform surgical repair of the aneurysm. We treated the patient medically with specific drugs for pulmonary arterial hypertension assuming to reduce the load pressure on the vascular wall of the pulmonary artery.

Discussion: We describe a very rare and extremely serious condition characterized by the concomitant presence of pulmonary arterial hypertension appropriately treated with effective triple oral combination therapy and inoperable pulmonary artery aneurysm with recurrent dissection.

\section{Keywords:}

Pulmonary arterial hypertension

Pulmonary artery aneurysm

Pulmonary artery dissection 


\section{Learning points}

Pulmonary arterial hypertension and pulmonary artery dissection are rare but life-threatening conditions.

Management of pulmonary arterial hypertension is known while there are no specific guidelines for treatment of pulmonary artery aneurysm.

When surgical treatment of pulmonary artery aneurysm is contraindicated, it is advisable to reduce the pressure load on the vessel wall.

\section{Introduction}

Pulmonary arterial hypertension (PAH) and pulmonary artery aneurysm (PAA) are rare conditions with severe complications and they often exist simultaneously. PAA is related to the stress that the vascular wall undergoes with progressive dilation of the artery. ${ }^{1}$ Although some authors have proposed a $4 \mathrm{~cm}$ cut-off, ${ }^{2}$ a clear definition of PAA is not available. ${ }^{3}$ Furthermore, life-threatening complications, such as dissection, airway compression, and thrombus formation in situ, are more common in patients with large aneurysm. ${ }^{4}$ Due to its low prevalence, the optimal management is still unclear. However, non-invasive imaging techniques have become more widespread, so the diagnosis of PA aneurysm, which was previously not recognized as a major problem, may become more frequent and a clinical problem in the near future. While the management of PAH is now widely shared ${ }^{5}$ and its prognosis has improved with the development of new drugs, it is unclear whether these therapies can also be effective to change the natural course of the PA aneurysm. Usually, lung transplantation (LTX) is the last treatment option for patients with end-stage $\mathrm{PAH}$. While, in patients with concomitant PAH and PAA heart-lung transplantation can be considered. We describe the case of a middle-aged woman with idiopathic PAH and inoperable giant PAA associated with recurrent pulmonary artery (PA) dissection, assuming to reduce the load pressure on the vascular wall with specific drugs for PAH.

\section{Case history}

In August 2015, a 62-year-old Caucasian woman presented to our hospital with acute shortness of breath and left-sided chest pain. Her prior medical evaluation revealed a history of vasoreactive $\mathrm{PAH}$ treated with calcium channel blockers with a slight PA dilatation about fifteen years ago. Her electrocardiogram revealed negative precordial T-wave and chest radiography showed cardiome-
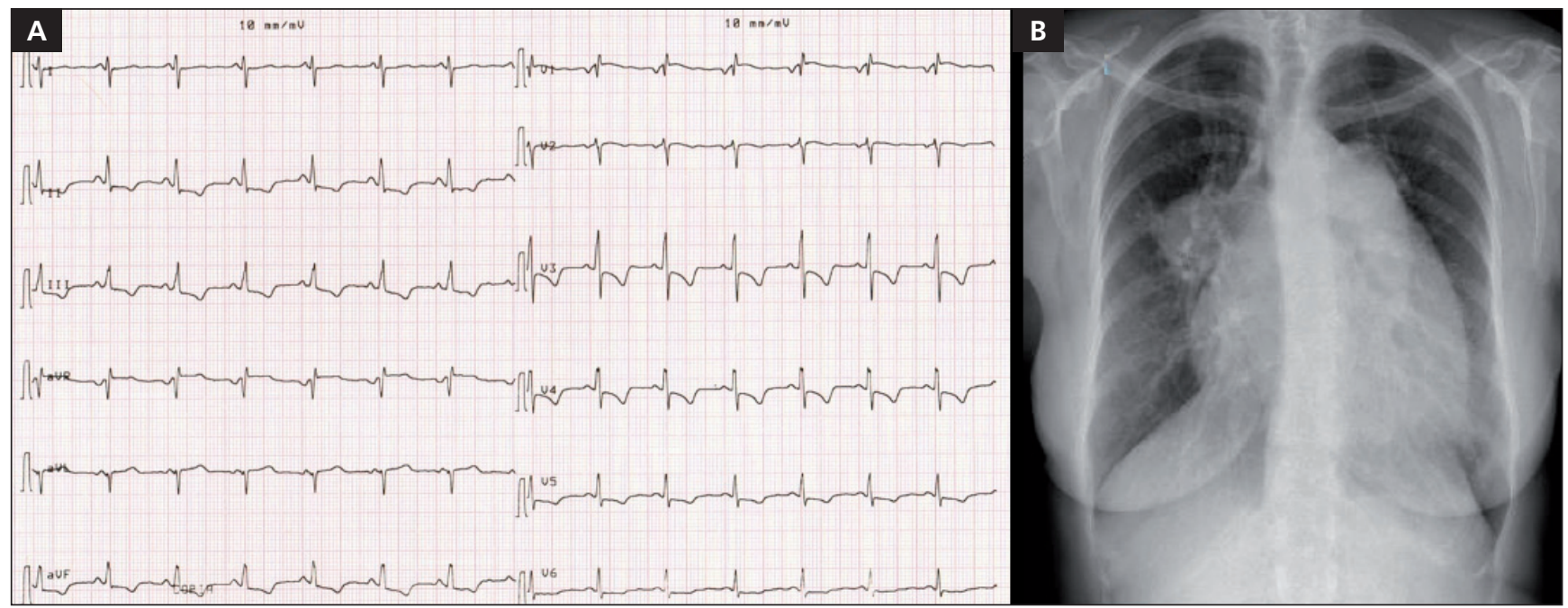

Fig. 1 - (A) Electrocardiogram showing widespread alterations of the ST-T segment. (B) Chest radiography demonstrating cardiomegaly, marked mediastinal enlargement occupying the left thorax and deviation of the carina.

\section{TIMELINE}

August 2015

September 2015

December 2015

February 2016

2016-2017

August 2018

January 2019

5th February 2021

28th February 2021
Diagnosis of pulmonary artery aneurysm and pulmonary arterial hypertension

Up-front combination therapy (ambrisentan and tadalafil) for pulmonary arterial hypertension

Improvement of symptoms and pulmonary hemodynamic parameters

First dissection of pulmonary artery without cardiac surgery

Clinical stability

Clinical worsening and add-on therapy for pulmonary arterial hypertension with selexipag

Improvement of symptoms and pulmonary hemodynamic parameters

Second dissection of pulmonary artery without cardiac surgery

Sudden death at home 


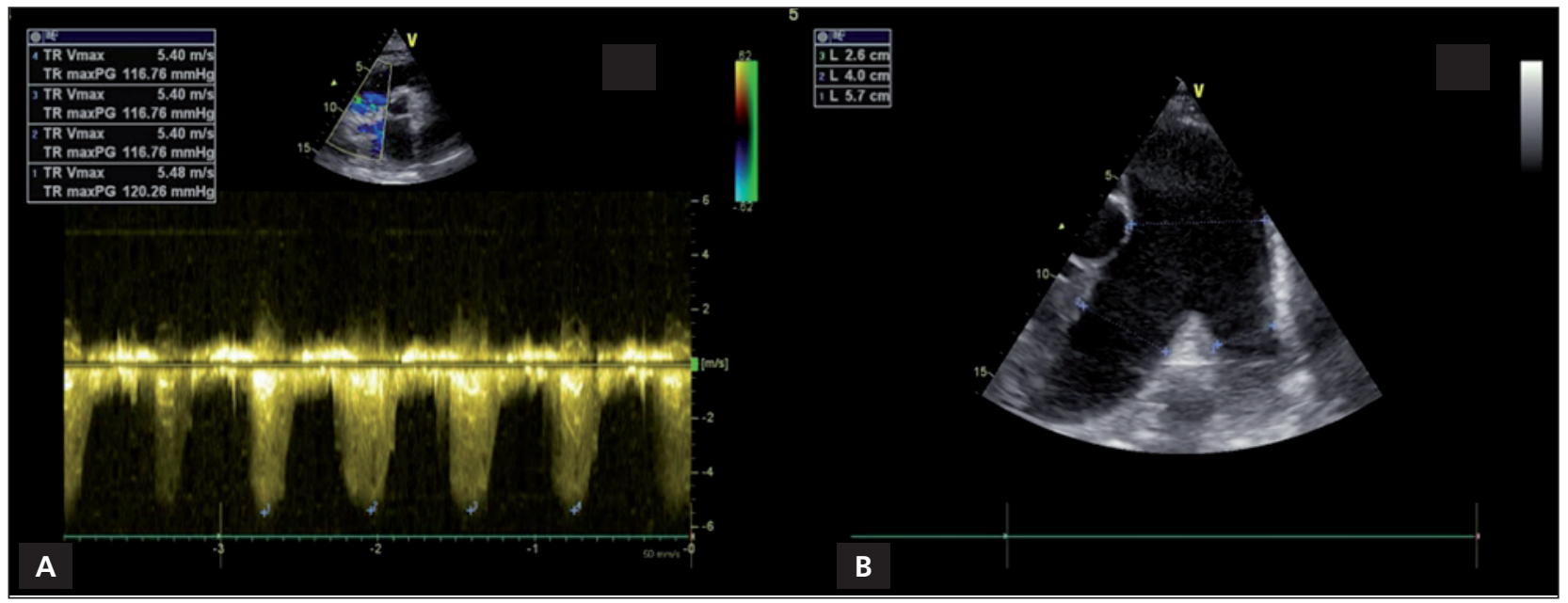

Fig. 2 - Basal transthoracic echocardiography showing a high value of pulmonary artery systolic pressure (A) and confirmed the dilatation of pulmonary artery (B).
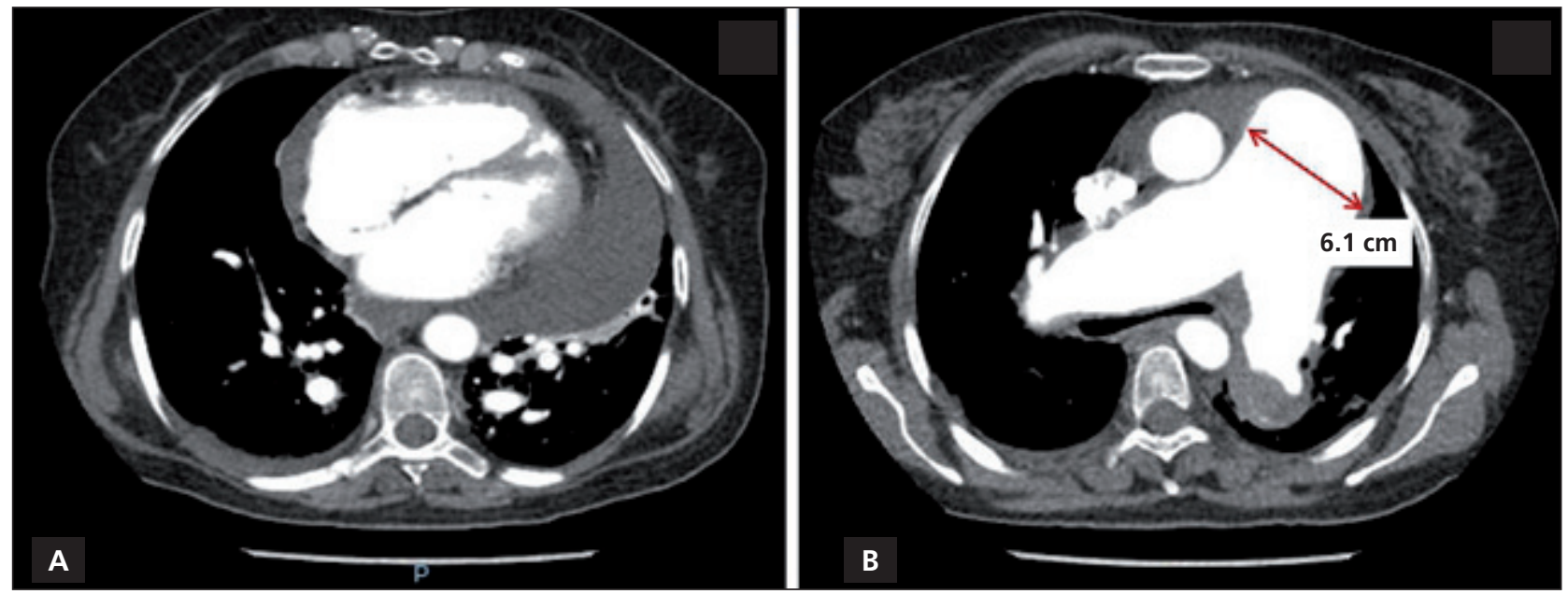

Fig. 3 - Computed tomographic angiography showing diffuse pericardial effusion (A) and thrombus in the right PA trunk, with aneurysm (maximum diameter $61 \mathrm{~mm}$ ) affecting the pulmonary artery and its main branches (B).

galy and dilation of the main pulmonary artery (Fig. 1). A transthoracic echocardiography (TTE) demonstrated: dilated right atrium and ventricle, severe systolic dysfunction (tricuspid annular plane systolic excursion [TAPSE] = 13), moderate tricuspid regurgitation with systolic pulmonary artery pressure (sPAP) of $120 \mathrm{mmHg}$, dilatation of the main PA $(57 \mathrm{~mm})$, right $(40 \mathrm{~mm})$ and left $(26 \mathrm{~mm})$ PA branches, moderate pulmonary regurgitation and diffuse and moderate pericardium effusion (Fig. 2). The left sided chambers were normal. High-sensitive troponin-T (0.066 ng/mL), d-dimer (3.6 mg/L) and NT-proBNP (988 ng/ $\mathrm{mL}$ ) levels were increased. At admission, in our cardiologic department, the patient was hemodynamically stable (heart rate: $70 \mathrm{bpm}$; blood pressure: 130/80 $\mathrm{mm} \mathrm{Hg}$ ) and fully asymptomatic. Considered clinical presentation suggesting acute pulmonary embolism or PA dissection, the patient underwent a computed tomographic (CT) angiography that showed an aneurysm affecting the main PA (Fig. 3) and thrombus in the trunk and right PA. Secondary causes for pulmonary hypertension $(\mathrm{PH})$ were excluded according to the protocol described in the $\mathrm{PH}$ guidelines of the European Society of Cardiology (ESC). ${ }^{5}$ A right cardiac catheterization showed a mean PA pressure (mPAP) of $69 \mathrm{mmHg}$ with a cardiac output (CO) of $2.6 \mathrm{~L} / \mathrm{min}$ and elevated pulmonary vascular resistance (PVR, $13.5 \mathrm{WU}$ ), with negative nitric oxide test. Cardiac surgeons consulted decline to perform surgical correction of the PAA, despite the possibility of impending rupture, because of the high peri-operative risk. The only remaining alternative was conservative but intensive treatment of the PAH by pharmacologic vasodilation. Therefore, the patient was treated with initial upfront combination therapy of PAH (tadalafil and ambrisentan) according to current PH guidelines of the ESC (Class I, LOE B). The patient was discharged from hospital without oral anticoagulation therapy (OAT) for the elevated risk of aneurysm rupture and potential indication for OAT in case of improvement of pulmonary hemodynamics. The patient's quality of life improved moderately and the right ventricular systolic pressure, as estimated by TEE, gradually decreased from $120 \mathrm{mmHg}$ to $90 \mathrm{mmHg}$. In February 2016, the patient was admitted again to our department with chest 


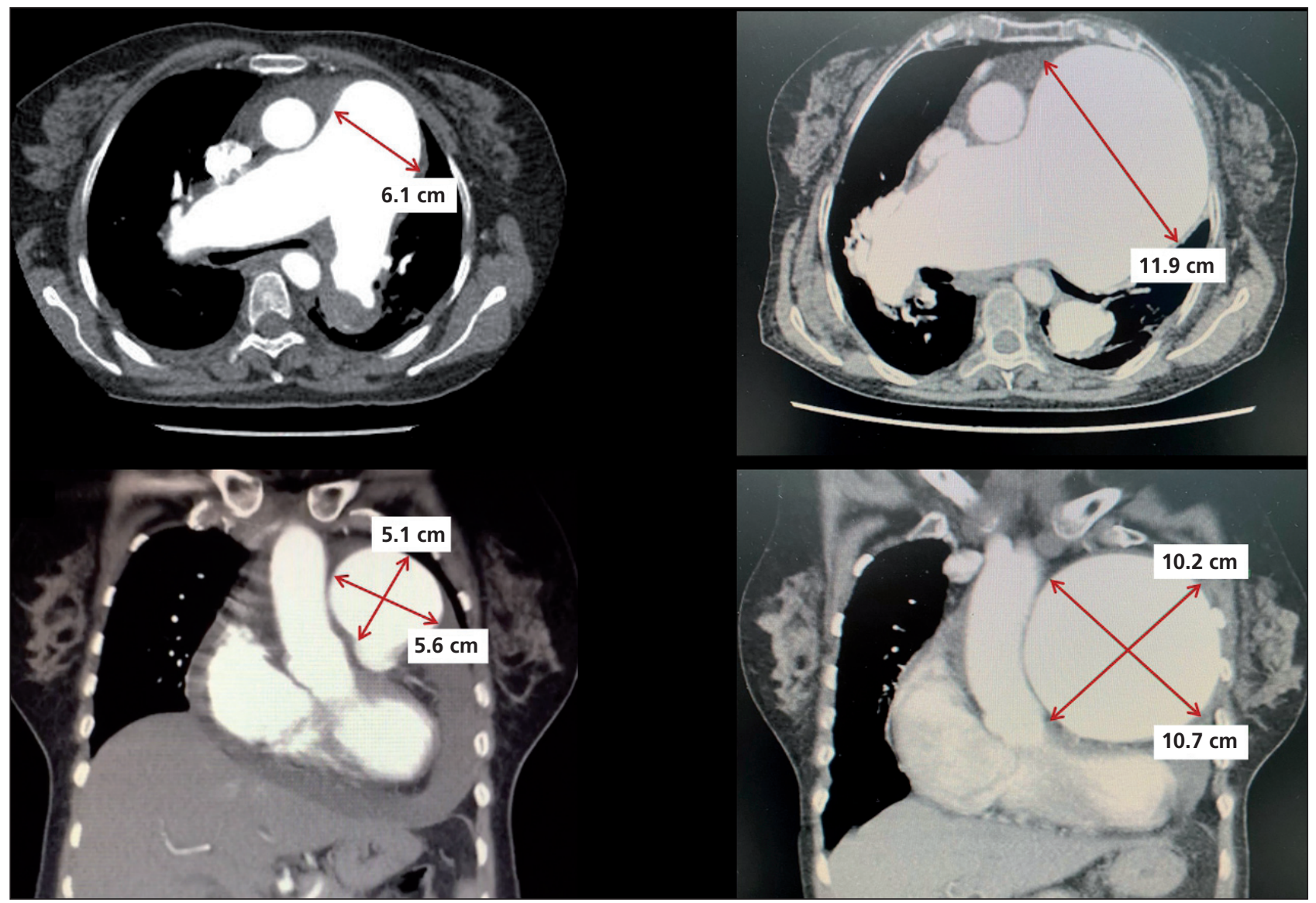

Fig. 4 - Computed tomographic angiography showing an increase of the pulmonary artery aneurysm: increased from 2015 - maximum diameter $61 \mathrm{~mm}$ - to 2021 - maximum diameter $119 \mathrm{~mm}$.

pain. CT scan showed, beyond the known dilation of PA, a small and linear dissection. Despite the expected complication, the patient was stable during hospitalization with improvements of previous described symptomatology. Excluding for the second time the surgical strategy, ${ }^{6}$ we decided to continue with the initial pharmacological strategy. The patient had an uneventful 18-month period follow-up with two specific drugs of PAH and OAT, with outpatient checks every three months. During this period, the control right cardiac catheterization showed mPAP of $37 \mathrm{mmHg}$ with a $\mathrm{CO}$ of $3.2 \mathrm{~L} / \mathrm{min}$. Regardless of the noticeable improvements of right cardiac pressures the patient maintained a moderate pulmonary regurgitation and stable dilation of main PA on TTE. In August 2018, the patient presented clinical worsening (FC WHO III) and selexipag was added and titrated up to the maximum tolerated dose of $1200 \mu \mathrm{g}$ BID. During the follow-up, in the suspicion of the left main coronary artery extrinsic compression, ${ }^{7}$ coronary angiography was recommended. The patient, however, refused. Therefore, myocardial scintigraphy and coronary CT scan was performed with negative results. In January 2019, the patient presented in functional class WHO II with NT-proBNP of $266 \mathrm{ng} / \mathrm{mL}$ and ETT confirmed the unchanging "reverse remodeling" of the right ventricle. In February 2021 the patient went to the emergency room for chest pain. TTE showed linear dissection of PA and severe pericardial effusion. CT scan confirmed a dramatic increase in the size of the PA aneu- rysm with associated dissection and limited hemorrhagic spread (Fig. 4). The patient was transferred to the cardiac surgery department, but a conservative strategy was chosen once again. The patient was discharged in 8 days asymptomatic and stable, with indication to continue the therapy but she died suddenly at home 20 days later.

\section{Discussion}

We have described a rare case of PAA with recurrent vessel dissection not susceptible to surgical correction in a patient with idiopathic PAH treated with triple oral specific therapy 7,8 and it highlights the difficulties in managing these rare patients. Timing of eventual surgical repair of PAA is difficult to detect, especially when PAH drug therapy is effective, and the patient cannot be a candidate for lung transplantation. Furthermore, in the presence of a giant PAA, the indication for heart and lung transplantation becomes even more difficult due to the small number of potential donors. Although the association between PA dilation and PAH is frequent, several authors suggest that the natural history of PAA is independent of the treatment of $\mathrm{PAH}^{9,}{ }^{9} 10 \mathrm{It}$ may rather be related to structural changes in the vessel wall. ${ }^{11-13}$ Fluid hemodynamics is governed by the Law of Laplace, according to which the wall stress is directly proportional to the pressure and radius of the vessel wall and is inversely 
proportional to the wall thickness. Increasing the radius and reducing the wall thickness increases the tension required to counterbalance the pressure. If the wall fails to develop the necessary tension, the dilation of the vessel increases again, making the aneurysm permanent. When the parietal tension becomes insufficient to counteract the internal pressure, the vessel goes through rupture The pulmonary artery is defined "aneurysmal" when it exceeds the normal upper limit of diameter of $2.9 \mathrm{~cm}$, even if some authors have proposed a cut-off of $4 \mathrm{~cm}^{14}$ reaching up to 6 or $8 \mathrm{~cm}$ to define "giant" PAA. ${ }^{15}$ From the few data in the literature, the sudden rupture of the PAA determines a mortality risk that reaches $100 \% .^{16}$

The approximate incidence of PAA is $1: 14000^{17}$ and it recognizes several causes, with a strong and frequent correlation with PAH.

\section{Classification}

Aneurysm of the pulmonary artery is often an underdiagnosed disease. Today non-invasive diagnostic instrumental investigations allow an occasional but fundamental feedback to implement therapeutic strategies that can slow the course of the disease. As mentioned above and as shown in literature ${ }^{18,19}$ there can be numerous triggers, differentiating them into congenital and acquired (Table 1). Among the congenital causes we classify left-right shunt pathologies, represented by Eisenmenger syndrome, ${ }^{20}$ manifested in adulthood; congenital valvulopathies such as pulmonary valvular stenosis or absent pulmonary valve syndrome; connective tissue alterations that include numerous diseases as Marfan syndrome, ${ }^{21}$ Ehler-Danlos disease, Williams-Beuren syndrome ${ }^{22}$ and tuberous sclerosis. ${ }^{23}$

In the acquired causes aneurysms deserve attention due to infections. Historically, diseases such as syphilis and tuberculosis were the most common cause. Manifested with fever, coughing and wheezing, agents such as fungi,

\begin{tabular}{|c|c|}
\hline CONGENITAL & ACQUIRED \\
\hline $\begin{array}{l}\text { Increased pulmonary blood flow } \\
\text { (Eisenmenger's syndrome) }\end{array}$ & $\begin{array}{l}\text { Pulmonary artery } \\
\text { hypertension (PAH) }\end{array}$ \\
\hline $\begin{array}{l}\text { Congenital valvulopaties (pul- } \\
\text { monary valvular stenosis, absent } \\
\text { pulmonary valve syndrome) }\end{array}$ & $\begin{array}{l}\text { Infections (bacteria, } \\
\text { fungi,viruses) }\end{array}$ \\
\hline \multirow{5}{*}{$\begin{array}{l}\text { Connectivitis abnormalities } \\
\text { (Marfan syndrome, Ehler-Danlos } \\
\text { disease, Williams-Beuren syn- } \\
\text { drome, tuberous sclerosis) }\end{array}$} & Malignancy \\
\hline & $\begin{array}{l}\text { Idiopathic pulmonary artery } \\
\text { aneurysm (IPAA) }\end{array}$ \\
\hline & $\begin{array}{l}\text { Autoimmune diseases and } \\
\text { vasculitis (Behçet's disease } \\
\text { syndrome, Hughes Stovin } \\
\text { syndrome) }\end{array}$ \\
\hline & latrogenic \\
\hline & Traumatic \\
\hline
\end{tabular}

IPAA - idiopathic pulmonary artery aneurysm; PAH - pulmonary arterial hypertension. bacteria, and viruses of any kind can be the cause. About the viruses, a case due to infection with SARS-CoV-2 was recorded this year. ${ }^{24}$ Among other causes we also consider those from pulmonary hypertension, as in our case, iatrogenic and for accidental trauma. Generally, all aneurysms caused by infection, iatrogenic causes or accidental trauma, are called pseudoaneurysms. Aneurysm of the pulmonary artery is a very frequent component also in autoimmune diseases and vasculitis; of all Bechet syndrome and Hughes Stovin Syndrome (HSS) are among the most frequently associated pathologies to the PAA. ${ }^{25,26} \mathrm{We}$ must also consider the idiopathic pulmonary artery aneurysm (IPAA), described for the first time by Wessler and Jaches, ${ }^{27}$ whose diagnosis in the past was based on cardiac catheterization or autopsy. Today with improvements in scientific technology and in particular echocardiography, or second level exams as cardiac magnetic resonance (CMR) and cardiac computed tomography, more cases are diagnosed..$^{28}$ Last but not least, there is a correlation with malignant tumors, especially lung cancer.

\section{Management of PAA}

The management of PAA is not defined by specific guidelines; therefore the best treatment is decided based on the patient's medical history. According to the literature, conservative treatment could be recommended in pulmonary hypertension with hemodynamic stability, recommending regular follow-up for aneurysm size monitoring. ${ }^{29,30}$ The drugs used in this case correspond to vasoactive substances: phosphodiesterase type 5 inhibitors, endothelin receptor antagonists, and prostacyclin derivatives, as indicated by the guidelines.

Surgery treatment represents the strategy most encouraged although not always applicable. Many patients with severe pulmonary hypertension or poor respiratory function are not eligible for surgery such as lobectomy and aneurysmectomy. In these cases selective endovascular transcatheter embolization approach may be preferred, in which through a femoral access a pigtail catheter is localized at the bifurcation of the pulmonary trunk delineating the vascular anatomy. Then aneurysma is eliminated using embolic agents.

Furthermore, the surgical option becomes more indicated when PAH with right heart failure is also present. ${ }^{31}$ Some authors have suggested that surgical intervention is recommended due to complications, ${ }^{32,33}$ while conservative management is an option when changes in right ventricular size are observed. ${ }^{34}$ Another theoretical but extremely high-risk procedure would have been a graft repair of the PAA with repair/replacement of pulmonary valve. However, this strategy is clearly inadvisable in patients affected by PAH because the progression of pulmonary vascular and parenchymal disease may take a second major surgical intervention.

In our case, the treatment with triple oral combination therapy resulted in a marked improvement in pulmonary hemodynamic parameters and ineffective on the progression of the PA aneurysm. However, in our opinion, the reduction of pressure overload on a less resistant vessel wall, using a combined oral therapeutic approach may have contributed to reducing the risk of fatal vessel dissection for several years. 


\section{Conflict of interest}

The authors declare that they have no conflict of interest.

\section{References}

1. Butto F, Lucas JRV, Edwards JE. Pulmonary arterial aneurysm. A pathologic study of five cases. Chest 1987;91:237-241.

2. Barbour DJ, Roberts WC. Aneurysm of the pulmonary trunk unassociated with intracardiac or great vessel left-to-right shunting. Am J Cardiol 1987;59:192-194.

3. Johnston KW, Rutherford RB, Tilson MD, et al. Suggested standards for reporting on arterial aneurysms. Subcommittee on Reporting Standards for Arterial Aneurysms, Ad Hoc Committee on Reporting Standards, Society for Vascular Surgery and North American Chapter, International Society for Cardiovascular Surgery. J Vasc Surg 1991;13:452-458.

4. Sakuma M, Demachi J, Suzuki J, et al. Proximal Pulmonary Artery Aneurysms in Patients with Pulmonary Artery Hypertension: Complicated Cases. Intern Med 2007;46:1789_ 1793.

5. Galiè N, Humbert M, Vachiery JL, et al. 2015 ESC/ERS Guidelines for the diagnosis and treatment of pulmonary hypertension. The Joint Task Force for the Diagnosis and Treatment of Pulmonary Hypertension of the European Society of Cardiology (ESC) and the European Respiratory Society (ERS). Eur Heart J 2015;46(4):903-975.

6. Hou R, Ma GT, Liu XR, et al. Surgical treatment of pulmonary artery aneurysm: an institutional experience and literature review. Interact Cardiovasc Thorac Surg 2016;23:438-442.

7. Galiè N, Saia F, Palazzini M, et al. Left Main Coronary Artery Compression in Patients with Pulmonary Arterial Hypertension and Angina. J Am Coll Cardiol 2017;69:2808-2817.

8. Tulino V, Cacace C, Tulino D, et al. Clinical variants in Ebstein's anomaly. Int J Cardiol 2013;168:4969-4970.

9. Florczyk M, Wieteska M, Kurzyna M, et al. Acute and chronic dissection of pulmonary artery: new challenges in pulmonary arterial hypertension? Pulm Circ 2018;8:2045893217749114.

10. Sardo MA, Mandraffino G, Riggio S, et al. Effects of the angiotensin II receptor blocker losartan on the monocyte expression of biglycan in hypertensive patients. Clin Exp Pharmacol Physiol 2010;37:933-938.

11. Akagi S, Nakamura K, Sarashina T, et al. Progression of pulmonary artery dilatation in patients with pulmonary hypertension coexisting with a pulmonary artery aneurysm. J Cardiol 2018;71:517-522.

12. Imbalzano E, Dattilo G, Scarpelli M, et al. Left coronary artery fistula to right ventricle complicated heart failure in a patient on hemodialysis. Intern Emerg Med 2013;8:765-766.

13. Boerrigter B, Mauritz GJ, Marcus JT, et al. Progressive Dilatation of the Main Pulmonary Artery Is a Characteristic of Pulmonary Arterial Hypertension and Is Not Related to Changes in Pressure. Chest 2010;138:1395-1401.

14. Nguyen ET, Silva $\mathrm{Cl}$, Seely JM, et al. Pulmonary artery and pseudoaneurysms in adults: findings at $C T$ and radiography. AJR Am J Roentgenol 2007;188:W126-W134.

15. Reisenauer JS, Said SM, Schaff HV, et al. Outcome of surgical repair of pulmonary artery aneurysms: a single-center experience with 38 patients. Ann Thorac Surg 2017;104:1605-1610.
16. Park HS, Chamarthy MR, Lamus D, et al. Pulmonary artery aneurysms: diagnosis \& endovascular therapy. Cardiovasc Diagn Ther 2018;8:350-361.

17. Deterling RA Jr, Clagett OT. Aneurysm of the pulmonary artery; review of the literature and report of a case. Am Heart J 1947;34:471-499.

18. Kreibich M, Siepe M, Kroll J, et al. Aneurysms of the pulmonary artery. Circulation. 2015;131:310-316.

19. Duijnhouwer AL, Navarese EP, Van Dijk AP, et al. Aneurysm of the Pulmonary Artery, a Systematic Review and Critical Analysis of Current Literature. Congenit Heart Dis 2016;11:102109.

20. Gupta M, Agrawal A, lakovou A, et al. Pulmonary artery aneurysm: a review. Pulm Circ 2020;10:2045894020908780.

21. Chiu $P$, Irons $M$, van de Rijn M, et al. Giant pulmonary artery aneurysm in a patient with Marfan syndrome and pulmonary hypertension. Circulation 2016;133:1218-1221.

22. Ojha V, Pandey NN, Verma M, et al. Spontaneous pulmonary artery aneurysm in a case of Williams syndrome. J Cardiovasc Comput Tomogr 2020;14:e170-e171.

23. Dunet V, Qanadli SD, Lazor R, Beigelman-Aubry C. Multiple pulmonary artery aneurysms in tuberous sclerosis complex. BMJ Case Rep 2013;2013:bcr2012007911.

24. Khurram R, Karia P, Naidu V, et al. Pulmonary artery pseudoaneurysm secondary to COVID-19 treated with endovascular embolisation. Eur J Radiol Open 2021;8:100346.

25. Zhuang LL, Liu HM, Li GM, et al. Dural sinus thrombosis and giant pulmonary artery aneurysm in paediatric Behçet's disease. Clin Exp Rheumatol 2020;38:558-566.

26. El Jammal T, Gavand PE, Martin M, et al. [Hughes-Stovin syndrome: About one case in a young man with recurrent thrombosis and pulmonary artery aneurysm and literature review]. Rev Med Interne 2019;40:120-125. French.

27. Wessler H, Jaches L. Clinical Roentgenology of Disease of the Chest. Troy, NJ/New York: The Southworth Company; 1923:26.

28. Intan RE, Hasibuan FS, Nugraha RA, et al. Proximal Pulmonary Artery Aneurysm Secondary to Suspected Pulmonary Hypertension Treated with Conservative Therapy in Limited Resource Setting. Am J Case Rep 2019;20:1805-1811.

29. Kreibich M, Siepe M, Kroll J, et al. Aneurysms of the pulmonary artery. Circulation 2015;131:310-316.

30. Kalra-Lall A, Donaldson J, Martin C 3rd. Brief review: Pulmonary artery aneurysms and pseudoaneurysms. Int Cardiovasc Imaging 2019;35:1357-1364.

31. Pelenghi S, Primiceri $C$, Belliato $M$, et al. Is it time for a paradigm shift: Should double-lung transplant be considered the treatment of choice for idiopathic pulmonary arterial hypertension and giant pulmonary aneurysm? J Card Surg 2021;36:2996-2999.

32. Fakler $\mathrm{U}$, Mebus $\mathrm{S}, \mathrm{Kaemmerer} \mathrm{H}$, et al. A ticking time bomb: high pressure pulmonary artery aneurysm. Am J Med 2008;121:777-780.

33. Tulino D, Imbalzano E, Casale M, et al. Treatment failure of low molecular weight heparin in diabetic patient. Int J Cardiol 2013;168:e63-e64.

34. Veldtman GR, Dearani JA, Warnes CA. Low pressure giant pulmonary artery aneurysms in the adult: natural history and management strategies. Heart 2003;89:1067-1070. 